\author{
Jan Borowiec \\ Wroclaw University of Economics and Bussines \\ e-mail: jan.borowiec@ue.wroc.pl \\ ORCID: 0000-0002-5376-8780
}

\title{
THE CONVERGENCE AND SYNCHRONIZATION OF BUSINESS CYCLES IN THE EUROPEAN UNION AND THE EUROPEAN MONETARY UNION
}

KONWERGENCJA I SYNCHRONIZACJA

CYKLI KONIUNKTURALNYCH

W UNII EUROPESKIEJ

\section{ORAZ UNII GOSPODARCZEJ I WALUTOWEJ}

DOI: $10.15611 / \mathrm{pn} .2020 .3 .01$

JEL Classification: E32, F15, F44

\begin{abstract}
Summary: The main aim of the paper is to determine the similarities and differences in the convergence and synchronization of business cycles in the EU and EMU in 1995-2018. The secondary goals are the following: a) the identification of the core and peripheries of European business cycles; $b$ ) the effects of monetary integration and the level of economic development and scale of the economy on the convergence and synchronization of business cycles. The results from the descriptive statistics and the correlation and regression analyses are: 1) classical cycles have a relatively high and similar concordance with the EU and the EMU, while at the same time they are strongly divergent on recession; 2) synchronization of the growth cycles is more diversified than classical cycles; 3 ) there is a clear division between the core and peripheries of European business cycles; 4) convergence of cycles is much more diversified than their synchronization; 5) level of economic development and the scale of the economy have an important influence on the convergence and synchronization of business cycles.
\end{abstract}

Keywords: business cycles synchronization, cyclical convergence, international economic integration, European Monetary Union.

Streszczenie: Celem głównym artykułu jest określenie stopnia synchronizacji i cykli koniunkturalnych w UE i UGW w okresie 1995-2018. Celami dodatkowymi są: a) identyfikacja jądra i peryferii europejskich cykli koniunkturalnych; b) wpływ integracji walutowej oraz poziomu rozwoju gospodarczego i skali gospodarki na konwergencję i synchronizację cykli koniunkturalnych. Zastosowano metody statystki opisowej, analizę korelacji i analizę regresji. Konkluzje są następujące: 1) cykle klasyczne charakteryzują się stosunkowo wysoką i mało zróżnicowaną konkordancją z cyklami UE i EMU, a zarazem silną dywergencją recesji; 2) synchronizacja cykli wzrostu gospodarczego jest bardziej zróżnicowana niż cykli klasycz- 
nych; 3) istnieje wyraźny podział na jądro oraz peryferia europejskich cykli koniunkturalnych; 4) konwergencja cykli jest o wiele bardziej zróżnicowana niż ich synchronizacja; 5) poziom rozwoju gospodarczego oraz skala gospodarki mają istotny wpływ na konwergencję i synchronizację cykli koniunkturalnych.

Słowa kluczowe: synchronizacja cykli koniunkturalnych, konwergencja cykliczna, międzynarodowa integracja gospodarcza, europejska unia walutowa.

\section{Introduction}

Synchronization of business cycles is the most important criterion of optimal currency areas, as well as one of the conditions of the effective functioning of the European Monetary Union (EMU). Insufficient synchronization and cyclical divergences can create procyclical effects of the ECB's monetary policy in national economies, and can also be a serious obstacle in the coordination of monetary and fiscal policies among EMU member countries.

The main goal of the study is the determination of the similarities and differences in the convergence and synchronization of business cycles in the European Union (EU) and the EMU. The secondary goals are as follows: a) identification of the core and peripheries of European business cycles; b) the effects of monetary integration, level of economic development and size of economy on the convergence and synchronization of business cycles, both classical and growth cycles were considered. The research employed the following methods: 1) descriptive statistics for calculating the concordance of classical business cycles and cyclical dispersions; 2) correlation analysis for calculating the levels of business cycles' synchronization; 3 ) regression analysis for determination of the effects of currency integration and gravitational factors on the convergence and synchronization of business cycles. The study is based on the Eurostat and the Ameco data for the period 1995-2018.

\section{Literature review}

The economic literature on the synchronization of business cycles in the EU and the EMU is abundant. Research in this area is closely connected with the theory of optimal currency areas (Mundell, 1961; McKinnon, 1963; Kennen, 1969). The conducted research concentrated on the EU15 and EA12 and rarely included countries which joined the EU this century. The presented review of literature on synchronization of business cycles in the EU and the EMU covers selected papers published in the English-language journals.

Artis (2003) aimed to identify European business cycles, using GDP quarterly data for 23 countries, including 15 European ones, for the period 1970-2001. The cyclical component was estimated with the Hodrick-Prescott filter. Synchronization of cycles was measured as a correlation coefficient of the productivity gap. Apart of 
the correlation analysis, the paper also included different clustering methods of countries based on the similarity and dissimilarity of their cycles. The author concluded that the core of European business cycles is made up from the cycles in France, Germany, Austria, Italy, Belgium and Ireland; these cycles were most correlated with the EU15 cycles.

Camacho, Perez-Quiros, and Saiz (2008) analyzed the similarity of classical business cycles in 30 countries including $25 \mathrm{EU}$ member states. Using clustering methods they distinguished four groups of countries with one quite atypical comprising Ireland, Hungary and Poland.

Furceri and Karras (2008) studied the level of synchronization of business cycles in the EMU before and after the introduction of the euro in nine EMU countries as well as Denmark, Sweden and the UK. The authors measured the synchronization as a correlation coefficient of the cyclical component of GDP estimated with the Hodrick-Prescott and Baxter-King filters. They concluded that after the introduction of the euro, the EMU business cycles became more synchronized.

The problem of business cycles' synchronization in the EMU was also investigated by Konstantakopoulou and Tssionas (2011) who analyzed data from the period 19602009. The cyclical component was estimated with many filters and synchronization was measured with the use of correlation analysis and the ARDL (Autoreggresive Distributed Lag) Model. The results suggest the existence of a common European cycle based on the Belgian, German, French, Luxembourgian and Austrian cycles.

Aguiar-Conraria and Soares (2011) used wavelet analysis in their paper on the synchronization of business cycles among EU15 and EMU12 countries. They concluded that the core cycle is mainly the outcome of the French and German cycles with the support of the cycles in Belgium, Spain, Italy, the Netherlands and Austria. The biggest distance was observed for the cycles in Ireland, Greece, Portugal and Finland. As for countries outside the EMU, only the cycle in Denmark was correlated with the European one.

Gomez, Ortega, and Torgler (2012) studied the synchronization of business cycles among the EU countries from 1989 to 2010, employing correlation matrix and network analysis. The results indicate the stabilization of the cycles in the 'old' member states and the decreasing differences between the 'old' and the 'new' member states. Some countries were very successful in their business cycles' coordination (the Baltic countries, Hungary, and Slovenia), whereas others even experienced desynchronization (Bulgaria, Romania, Greece and Ireland).

Using the Bayesian Dynamic Factor Model, Lehwald (2013) analyzed the relations between changes of GDP in EA12 countries in two periods: 1991-1998 and 2000-2010. The authors' conclusions were the following: the introduction of the euro increased the synchronization of business cycles in the core countries and decreased it in the peripheral states; contrary to the hypothesis of the endogeneity of the optimal currency area criteria (Frankel and Rose, 1998), the monetary integration 
in the Eurozone has increased the cyclical imbalance between these two different groups of countries.

Papadimitriou, Gogas, and Sarantiti (2016) studied the convergence of the European business cycles in 1986-2011. They employed the Complex Networks Approach, where connectivity was represented by the Pearson correlation of GDP growth ratio. Their empirical results indicate that despite the idiosyncratic behaviour of a few economies, the business cycles of the European countries displayed an overall increased degree of synchronization and thus convergence in the single currency era.

Augustyński and Laskoś-Grabowski (2018) employed the hierarchical clustering method using the compression-based dissimilarity measure. The authors compared the time series of the GDPs of the EU Member States, covering three periods: 2000Q12007Q4, 2008Q1-2017Q1, and the complete period of 2000Q1-2017Q1. Their concluding remarks were that the Global Financial Crisis reversed the processes of economic integration within the EU. The employed similarity method allowed for distinguishing two main groups of countries: the 'core', i.e. France, Germany, the Netherlands, Austria, Belgium and Spain, and the 'periphery' - the other EU member states.

In their study, Santos and Rodriguez (2016) investigated the dynamics of European business cycles' synchronization in the period 1991-2013. The European core business cycle was estimated by means of a cyclical trend decomposition model, and a testing procedure was proposed to study the stability of the interdependencies between the GDP growth rates of the economies and the cyclical common factor. The results show an extended European business cycle moving toward the synchronization levels enjoyed by the core EMU countries (Belgium, Germany, France, Italy and the Netherlands). In the second group of periphery economies (mainly the economies of the EU enlargements of the 2000s), synchronization has increased since the beginning of the Great Recession.

Belke, Domnick, and Gros (2016) examined the synchronization of business cycles in the EMU with a special focus on the core-periphery pattern in the aftermath of the crisis. The authors concluded that the crisis did not weaken the strong synchronization of the cycles within the core EMU, but decreased the synchronization in the EMU periphery states, mostly in Greece.

Lastly, Gomez, Ferrari, Torgler, and Ortega (2017) employed a correlation matrix of the GDP cyclical component estimated by the Hodrick-Prescott filter and the network analysis method. Their analysis covered the period 1995-2015. The results indicated that the synchronization of the euro zone countries remained stable from 1999 until the Global Financial Crisis, after which co-movements increased sharply and synchronization rose to the highest in the time sample. They also confirmed the existence of the core and peripheries of the European business cycles in the EMU.

Summarizing, the results from the presented papers indicate the growth of synchronization of the European business cycles especially after the introduction of the euro, as well as the existence of the 'core' and the 'periphery'. The core cycles consist 
of only six EMU member states' cycles - Belgium, Germany, France, Italy, Netherlands and Austria, and two non-EMU countries i.e. Denmark and Sweden. The periphery countries face two different tendencies in the evolution of business cycles: convergence with the core cycle in the majority of countries, and divergence in others.

\section{Research methodology}

Convergence and synchronization are almost synonyms. Synchronization means increasing the timing of business cycles whereas convergence means similarity, and the concurrence of business cycles. Researching both these phenomena requires appropriate methods. The methods most commonly used in the analysis of business cycles' synchronization are: concordance analysis - for the classical cycles, and analysis of the cyclical component for the economic growth cycles. Cyclical convergence, that is the similarities and differences in the course of business cycles was investigated with the use of dispersion analysis, clustering methods, network methods and wavelet analysis.

The subject of the research is both the synchronization of the classical cycles in the EU and the EMU, and the economic growth cycles ${ }^{1}$. Dating of the classical business cycles is based on the changes of one or more indicators of economic activity. In the research, the differences between quarterly GDP data were used represented by the 2010 prices adjusted for seasonal and calendar fluctuations. The time period starts from the second quarter of 1995 and ends in the last quarter of 2018. The synchronization of business cycles is measured by the concordance index which represents the percentage share of periods where two GDP time series are in the same phase of cycle (recession or growth).

Dating of the classical business cycle was conducted according to the following algorithm (Burns and Mitchel, 1946; Harding and Pagan, 2002):

- in a given quarter, the cycle reaches its peak when the level of GDP is higher than in the two previous and two following quarters;

- in a given quarter, the cycle reaches its trough when the level of GDP is lower than in the two previous and two following quarters;

- every phase lasts for at least two quarters;

- a recession is defined as a decrease of GDP for at least the two following quarters;

- the phases of a cycle are alternating, and its length is not less than five quarters. Growth cycles' recognition is usually based on the changes in the cyclical component of real GDP i.e. the output gap. Its estimation requires appropriate statistical methods. The OECD, the IMF and the European Commission use an approach based on the production function. The output gap is calculated as the difference between real and potential GDP (as a percentage of potential GDP).

\footnotetext{
1 'Classical cycle' is understood as fluctuations of an economic activity whereas 'growth cycle' is defined as fluctuations of the cyclical component of the real GDP.
} 
Potential GDP is estimated from employment trends, NAIRU (non-accelerating inflation rate of unemployment) unemployment and the total effectiveness of production factors. Another approach uses frequency filters to extract the cyclical component of GDP (Hodrick and Prescott, 1997; Baxter and King, 1999; Christiano and Fitzgerald, 2003). The output gap estimated in this way is presented as a percentage of the GDP trend. The measure of synchronization of business cycles is an output gap correlation coefficient. In research on a cyclical component, the output gap is expressed as a percentage of potential GDP, whereas the measure of cycles' synchronization is the Pearson correlation coefficient.

The following problems are the subject of the paper:

- concordance of the national cycles with the EMU counterparts measured as the Harding-Pagan concordance index;

- recession similarity measured as the standard deviation of the absolute differences in the cumulated changes in GDP during a recession between the EMU and individual EU member countries (as \% of GDP in 2010);

- similarity of output gap measured as the standard deviation of the differences of levels of the production gap between the EMU and individual EU member countries;

- the correlation of national cycles with the EMU cycle measured as the correlation coefficient between the EMU output gap and the output gap in individual EU member countries;

- the identification of the core and the peripheries of the European business cycles based on the results of research on the convergence and synchronization of national cycles with the EMU counterparts.

The concordance of cycles and similarity of recessions relate to classical cycles, the similarity of the output gap and the cycles correlation relate to economic growth cycles. The similarity of the recession and the output gap are measures of cyclical convergence, whereas the concordance and correlation of cycles are measures of the synchronization of business cycles. The research employs methods of descriptive statistics (analysis of business cycles concordance and analysis of recession dispersion, and the cyclical component) as well as analysis of the correlation of an output gap. The source of data on the quarterly changes in real GDP is Eurostat (2019), whereas data on the output gap come from the annual macroeconomic data of the European Commission's Directorate General for Economic and Financial Affairs (AMECO, 2019). The study covers the period 1995-2018.

\section{Level of convergence and synchronization of business cycles}

Table 1 presents the results from the study of the level of convergence and synchronization of business cycles. It provides a list of countries ranked according to measures of convergence and synchronization. Since the measures of cyclical convergence are destimulants, cycles' similarity is bigger, the smaller the convergence 
Table 1. Convergence and synchronization of the business cycles in the EU and the EMU

\begin{tabular}{|c|c|c|c|c|c|}
\hline \multirow[b]{2}{*}{ Countries } & \multicolumn{2}{|c|}{ Classical cycles } & \multicolumn{2}{|c|}{ Economic growth cycles } & \multirow{4}{*}{ Ranking } \\
\hline & $\begin{array}{l}\text { Similarities of } \\
\text { the recessions }\end{array}$ & $\begin{array}{c}\text { Cyclical } \\
\text { concordance }\end{array}$ & $\begin{array}{l}\text { Output gaps } \\
\text { similarities }\end{array}$ & $\begin{array}{l}\text { Cycles } \\
\text { correlation }\end{array}$ & \\
\hline EU & 0.5 & 100 & 0.10 & 0.99 & \\
\hline EMU & 0.0 & 100 & 0.00 & 1.00 & \\
\hline \multicolumn{6}{|c|}{ EMU countries } \\
\hline Netherlands & 1.0 & 95.6 & 1.04 & 0.83 & 5.00 \\
\hline France & 3.7 & 93.7 & 0.88 & 0.87 & 5.25 \\
\hline Belgium & 3.0 & 92.6 & 0.95 & 0.85 & 6.50 \\
\hline Austria & 2.0 & 91.2 & 1.03 & 0.80 & 8.00 \\
\hline Italy & 7.5 & 90.5 & 0.84 & 0.90 & 8.75 \\
\hline Germany & 2.5 & 93.7 & 1.33 & 0.63 & 9.00 \\
\hline Finland & 6.4 & 91.6 & 1.14 & 0.88 & 9.25 \\
\hline Spain & 3.0 & 91.6 & 2.43 & 0.88 & 9.50 \\
\hline Slovenia & 7.4 & 97.9 & 1.95 & 0.86 & 10.00 \\
\hline Ireland & 5.8 & 93.7 & 1.68 & 0.80 & 10.50 \\
\hline Luxembourg & 3.9 & 87.4 & 1.54 & 0.86 & 11.00 \\
\hline Portugal & 7.4 & 87.4 & 1.24 & 0.75 & 13.75 \\
\hline Cyprus & 5.7 & 87.4 & 2.80 & 0.83 & 14.25 \\
\hline Malta & 0.6 & 82.7 & 1.67 & 0.48 & 15.25 \\
\hline Slovakia & 3.7 & 84.2 & 2.80 & 0.38 & 19.25 \\
\hline Estonia & 19.3 & 89.5 & 4.95 & 0.55 & 21.25 \\
\hline Lithuania & 13.7 & 86.3 & 4.01 & 0.44 & 22.00 \\
\hline Greece & 24.0 & 82.1 & 5.79 & 0.67 & 23.75 \\
\hline Latvia & 23.2 & 80.0 & 4.13 & 0.61 & 24.00 \\
\hline \multicolumn{6}{|c|}{ Non-EMU Countries } \\
\hline Sweden & 0.5 & 93.7 & 1.11 & 0.80 & 5.75 \\
\hline Denmark & 3.3 & 87.4 & 1.09 & 0.97 & 7.75 \\
\hline Czechia & 0.4 & 92.3 & 1.97 & 0.61 & 11.00 \\
\hline Hungary & 2.8 & 87.4 & 1.70 & 0.68 & 12.50 \\
\hline Croatia & 7.7 & 81.3 & 2.00 & 0.66 & 20.25 \\
\hline Poland & 6.3 & 86.3 & 2.82 & -0.06 & 20.75 \\
\hline Romania & 9.4 & 83.2 & 3.95 & 0.41 & 22.50 \\
\hline Bulgaria & 17.3 & 83.2 & 4.81 & -0.04 & 24.00 \\
\hline \multicolumn{6}{|c|}{ Mean and dispersion } \\
\hline Median & 5.7 & 87.4 & 1.675 & 0.775 & 10.00 \\
\hline Mean & 7.1 & 88.7 & 2.28 & 0.66 & 13.69 \\
\hline$\Delta$ & 6.60 & 4.71 & 1.40 & 0.26 & 6.37 \\
\hline M & 92.90 & 5.31 & 61.36 & 39.57 & 46.55 \\
\hline
\end{tabular}

Notes: EMU - European Monetary Union; EU - European Union; $\delta$ - standard deviation; $\mu$ - coefficient of variation.

Source: own study based on Eurostat (2019) and AMECO (2019). 
values. The ranks are calculated as an arithmetic average of the sum of the rankings of individual measures of convergence and synchronization.

The indexes of concordance cycles in the EU are relatively high (mean $=88.7$ median =87.4). The highest concordance with the EU and the EMU cycles is shown for Slovenia, Austria, Belgium, Sweden and the Netherlands, while the relatively lowest concordance for Romania, Croatia, Malta, Latvia and Bulgaria. However, the indicators of dispersion of concordance indexes are low which suggests that cycles' concordance is low in the member countries.

The results of the study on the similarities of recession suggest the existence of divergence in this phase of the business cycle. The Great Recession in 2008-2009, and two other recessions, decreased real GDP by $7.7 \%$ in the EMU, and $7.2 \%$ in the EU. The economic effects in the member states were very diverse. The recessions were most similar to those in the EMU in Czechia, Sweden and Malta, and least similar in Greece, Latvia, Estonia, Bulgaria and Lithuania. The reaction to the recession, especially the Great Recession, was more diverse within the EMU than in other countries. The disparity in the reactions to the Great Recession by the European economies indicates both the disparity in their susceptibility to economic and financial shocks, and the different role of the mechanisms of macroeconomic stabilization, mostly market and financial ones.

The results of studies on the convergence and synchronization of economic growth cycles are more diverse. Business cycles in the member states are more or less synchronized with the EMU cycles except for Bulgaria and Poland, whose cycles are characterized by a small desynchronization with the EMU cycles. Synchronization is the strongest in Denmark and Italy and the weakest in Slovakia, Malta, Lithuania, Latvia and Romania. Comparatively weak synchronization with the EMU cycles is show also by German cycles, although it constitutes an important part of the European cycle. The German cycles were considerably different than the EMU cycles at the beginning of this century and during the boom following the Great Recession. The results of analysis of the convergence of growth cycles also show important differences in output gaps. The smallest differences between the domestic output gap and the EMU are in Italy, France, Belgium, Austria and the Netherlands, whereas the biggest are in Greece, Estonia, Bulgaria, Latvia and Lithuania.

The member states are more diversified in their convergence of cycles than in synchronization. The correlation analysis showed that the interdependence of both phenomena is rather weak. The correlation coefficient between the similarity of recession and the classical cycles' concordance is -0.52 , and the correlation between the similarity of an output gap and synchronization of growth cycles is $-0.58^{2}$. In extreme cases, the discrepancy between measures of convergence and synchronization is very large, this applies above all to Germany and Poland. The differences in the output gap levels between Germany and the EMU are one of the smallest, whereas the level of German business cycles' synchronization with the EMU is lower than in

\footnotetext{
${ }^{2}$ Own calculations.
} 
most European countries, where Desynchronization of cycles took place in 2004-2005, 2011-2012 and 2016. Additionally, the boom after the Great Recession in Germany was much stronger than in the EMU. The output gap in Poland was more convergent with its EMU counterpart than in Greece, Estonia, Latvia and Lithuania. Nevertheless the business cycles in Poland were not synchronized with the EMU, whereas the cycles in four of these countries are synchronized, and in Greece the synchronization is even higher than in Germany. These untypical characteristics of the Polish business cycles were also pointed out by other studies (Camacho et al., 2008; Santos and Rodriguez, 2016; Gomez et al., 2017).

Concluding, the results of the study are not essentially different from these presented in the literature review. Some discrepancies could come from differences in methodology, number of countries included and (mostly) from the different length of time series.

\section{Core vs periphery of the European business cycles}

The similarities and differences in the convergence and synchronization of business cycles indicate the existence of a core and periphery of the European business cycles. The identification of cycles in countries constituting the core and periphery are based on the median of the convergence and synchronization values and ranking, presented in Table 1. In order to identify the core of the European business cycles it was assumed that measures of cyclical convergence are lower than median, whereas measures of cycles' synchronization are higher or the corresponding ranking is higher than median. The periphery cycles were classified according to the distance of national cycles (understood as the differences in dispersion of the measures of convergence and synchronization measures) from the European cycles core.

The following three groups of countries were distinguished:

- The core of the European business cycles characterized by the highest convergence and synchronization of national cycles with the EMU cycles. This group consists of seven EMU countries (Belgium, Germany, France, Italy, the Netherlands, Austria and Finland) and two other countries (Denmark and Sweden). All these countries are more developed member states ${ }^{3}$ And, except for Spain and Italy, their GDP per capita considerably exceeds the EU average. The core economies also have the biggest share in total GDP of the EU27 (84.2\% in 2017 (Eurostat, 2019).

- Convergence towards the core of the European business cycles. Convergence is present in six EMU member states (Ireland, Cyprus, Luxembourg, Malta, Portugal and Slovenia) and two additional countries (Czechia and Hungary). These are relatively small economies in different stages of economic development.

${ }^{3}$ The European Union distinguishes three categories of member states: less developed - GDP per capita below $75 \%$ of the EU average, transition - GDP per capita ranging from $75 \%$ to $90 \%$ of the EU average and more developed regions: GDP per capita above $90 \%$ of the EU average. 
GDP per capita in Luxembourg and Ireland is the highest in the EU, whereas Hungary remains a less developed country. The size of these economies makes them more specialized and open to international trade which simultaneously exposes them to specific economic shocks.

- The peripheries of the European business cycles comprise less developed countries (Bulgaria, Greece, Croatia, Latvia, Poland, and Romania) as well as, until their recent transition, Estonia, Lithuania, and Slovakia; most of these countries are members of the EMU.

Table 2 presents the results of the study on the differences in the level of the convergence and synchronization of business cycles in individual countries.

Table 2. Diversity in convergence and synchronization of the business cycles

\begin{tabular}{|l|c|c|c|c|}
\hline \multirow{2}{*}{ Indicators } & \multicolumn{2}{|c|}{ Classical cycles } & \multicolumn{2}{c|}{\begin{tabular}{c} 
Economic growth cycles \\
\cline { 2 - 4 }
\end{tabular}} \\
\cline { 2 - 5 } & $\begin{array}{c}\text { Similarities } \\
\text { of the recessions }\end{array}$ & $\begin{array}{c}\text { Cycles } \\
\text { concordance }\end{array}$ & $\begin{array}{c}\text { Similarities of the } \\
\text { output gaps }\end{array}$ & $\begin{array}{c}\text { Cycles } \\
\text { correlation }\end{array}$ \\
\hline \multicolumn{5}{|c|}{ Core of the European cycles } \\
\hline Median & 3.00 & 93.10 & 1.10 & 0.86 \\
\hline Mean & 3.29 & 92.16 & 1.18 & 0.84 \\
\hline$\delta$ & 2.07 & 2.15 & 0.44 & 0.08 \\
\hline \multicolumn{5}{|c|}{ Convergence on the core of the European cycles } \\
\hline Median & 4.8 & 87.4 & 1.69 & 0.77 \\
\hline Mean & 4.25 & 89.5 & 1.82 & 0.73 \\
\hline$\delta$ & 2.62 & 4.47 & 0.43 \\
\hline \multicolumn{5}{|c|}{ Periphery of the European cycles } \\
\hline Median & 15.5 & 83.2 & 4.01 & 0.13 \\
\hline Mean & 13.8 & 84.0 & 3.92 & 0.40 \\
\hline$\delta$ & 7.07 & 2.77 & 1.13 & 0.26 \\
\hline
\end{tabular}

Notes: $\delta$ - standard deviation.

Source: own study.

In the first group of countries, i.e. the core, national cycles are both strongly synchronized with the EMU cycles and have most similar recessions and output gap patterns. The levels of convergence and synchronization in the second group are lower than in first one, but considerably higher than in the third group. In three countries from the last group - Slovenia, Ireland and Luxembourg - the cycles are most similar to the core cycles. Except for Greece, this group constitutes the majority of the Central and East European countries.

Considering the composition of particular groups, no strong relation between monetary integration and convergence or synchronization could be found. The EMU countries are present in all groups, although the majority of them belong to the core of the European business cycles. The four biggest European economies (Germany, 
France, Italy and Spain), which account for three-quarters of the EMU's GDP, are among them. A stronger relation exists between economic development and convergence or synchronization. More developed EMU countries including Denmark and Sweden make up the core group, whereas less developed countries constitute the periphery.

The results of the study are yet again not very different from previous research aimed at distinguishing the core and peripheries of the European business cycles. Convergence and synchronization are characterized by inertia caused in general by structural factors whose evolution is slow and long. The dynamics of structural changes could be diverse and in some circumstances even regressive.

\section{Monetary integration, economic development and size of economy versus convergence and synchronization of business cycles}

Analysis of the composition of the countries constituting the core and periphery of the European business cycles provides two conclusions concerning the role of gravitational factors i.e. level of economic growth, size of economy and monetary integration in the convergence and synchronization of business cycles. The relations among these factors became an additional goal of the research, And in order to

Table 3. Results of the regression analysis

\begin{tabular}{|l|l|l|l|}
\hline \multicolumn{1}{|c|}{ Dependent variable } & \multicolumn{3}{c|}{$\begin{array}{c}\text { Ranking of the measures of the convergence } \\
\text { and business cycles synchronization }\end{array}$} \\
\hline \multicolumn{1}{|c|}{ Independent variables } & \multicolumn{1}{|c|}{$\begin{array}{c}\text { Monetary } \\
\text { integration }\end{array}$} & \multicolumn{1}{c|}{$\begin{array}{c}\text { GNI per capita } \\
\text { in PPS }\end{array}$} & $\begin{array}{c}\text { Volume of the GDP } \\
\text { in PPS }\end{array}$ \\
\hline $\mathrm{n}$ & 27 & 27 & 27 \\
$\mathrm{y}$ & 13.69 & 13.69 & 13.69 \\
$\mathrm{x}$ & 0.55 & 30.6 & 3.7 \\
$\alpha$ & 15.46 & 28.57 & 16.60 \\
$\beta$ & -4.01 & -0.49 & -0.79 \\
$\mathrm{r}^{2}$ & 0.14 & 0.51 & 0.51 \\
regression function & $\mathrm{y}=15.46-4.01 \mathrm{x}$ & $\mathrm{y}=28.57-0.49 \mathrm{x}$ & $\mathrm{y}=16.6-0.79 \mathrm{x}$ \\
$\mathrm{RSS}$ & 940.19 & 536.04 & 533.15 \\
$\mathrm{SE}(\alpha)$ & 1.60 & 3.04 & 1.04 \\
SE $(\beta)$ & 1.97 & 0.10 & 0.15 \\
$95 \%$ confidence interval for $\alpha$ & {$[12.73 ; 18.19]$} & {$[23.38 ; 33.76]$} & {$[14.82 ; 18.38]$} \\
$95 \%$ confidence interval for $\beta$ & $[-0.76 ; 4.70]]$ & {$[-0.07 ; 0.27]$} & {$[-0.11 ; 0.41]$} \\
\hline
\end{tabular}

Notes: $\mathrm{n}$ - number of observations; $\mathrm{y}$ - dependent variable mean; $\mathrm{x}$ - independent variable mean; $\alpha, \beta$ - regression coefficients; $\mathrm{r}^{2}$ - coefficient of determination; RSS - residual sum of squares; SE $(\alpha)$, SE $(\beta)$ - standard errors of regression coefficients.

Source: own study. 
achieve it regression analysis was employed. The ranking of convergence measures and business cycles' synchronization was adopted as the dependent variable whereas the independent variables included: 1) monetary integration, 2) Gross National Income (GNI) per capita in purchasing power standards (PPS), 3) volume of the Gross Domestic Product (GDP) in PPS. Monetary integration was measured as the ratio of how many years a given country has been using the euro to the whole period of the operation of the EMU. The parameters of the regression function were estimated with the use of the standard least squares method; the results are presented in Table 3.

Linear regression analysis confirms the findings based on the study of the composition of the core and peripheries of the European business cycles. The relation between using the euro and convergence and synchronization is weak. Monetary integration influences an economy mainly through monetary policy i.e. changes in the real short-term interest rate and the real effective exchange rate, however gravitational factors play a stronger role. The level of economic development represents a variety of structural factors including specialization in international trade - the most important determinant of synchronization of business cycles. The size of an economy determines its ability to influence other economies through international flows of goods and services or factors of production.

\section{Conclusion}

Classical business cycles in the member states are characterized by relatively high and undiversified concordance with the EMU cycles and simultaneously they have strong divergences of the recession phase of a cycle. These divergences reflect to some extent the structural differences in the EU, which could be connected both to the vulnerability of economies to economic and financial shocks and to the role of market and fiscal mechanisms of adjustment and stabilization.

The synchronization of growth cycles is much more diverse than the concordance of classical cycles. Two types of countries can be easily distinguished: the core and the periphery of the European business cycles. In the core countries, the cycles are highly synchronized much more than in the periphery. There is no observed relation between monetary integration and the convergence or synchronization of business cycles, however such a relationship can be found between economic development or economy size and convergence and synchronization. The core is made up by more developed countries which include the biggest European economies, while the periphery is formed by the less developed states. The results of the study corroborate the conclusions from the literature review related to synchronization of cycles in the EU and the EMU, especially the results of the identification of the core and periphery of the European business cycles.

The EU and the EMU member states are more diversified in convergence than in synchronization of business cycles. The dispersion indicators are higher for 
convergence measures than for synchronization measures especially in the EMU countries. The interdependence of these two phenomena is thus rather weak. This justifies the extension of the research on the synchronization of business cycles with studies on their convergence, i.e. the similarities and differences in the broadly understood cyclical conditions of an economy.

\section{References}

Aguiar-Conraria, L., and Soares, M. J. (2011). Business cycle synchronization and the Euro: A wavelet analysis. Journal of Macroeconomics, (33), 477-489.

AMECO. (2019). Retrieved from http://ec.europa.eu/economy_finance/ameco/user/serie/SelectSerie.cfm

Artis, M. (2003). Is there a European business cycle? (CESifo Working Paper, No. 1053).

Augustyński, I., and Laskoś-Grabowski, P. (2018). Clustering macroeconomic time series. Econometrics. Ekonometria. Advances in Applied Data Analysis, (22), 74-88.

Baxter, M., and King, R. (1999). Measuring the business cycle: Approximate band-pass filters for economic time series. Review of Economic and Statistics, (81), 575-593.

Belke, A., Domnick, C., and Gros, D. (2016). Business cycle synchronization in the EMU: Core vs. periphery. (CEPS Working Document, No. 427).

Burns, A., and Mitchel, W. (1946). Measuring business cycles. New York: National Bureau of Economic Research.

Camacho, M., Peres-Quiros, G., and Saiz, L. (2008). Do European business cycles look like one? Journal of Economic Dynamics and Control, (32), 2165-2190.

Christiano, L. J., Fitzgerald, T. J. (2003). The band pass filter. International Economic Review, (44), 435-465.

Darvas, Z., and Szapáry, G. (2008). Business cycle synchronization in the enlarged EU. Open Economies Review, (19), 1-19.

Denis, C., Mc Morrow, K., and Röger, W. (2002). Production function approach to calculating potential growth and output gaps - estimates for the EU Member States and the US. European Economy Economic Papers, No. 176.

Eurostat. (2019). Retrieved from http://appsso.eurostat.ec.europa.eu/nui/show.do?dataset=namq 10 gdp\&lang=en

Frankel, J. A., and Rose, K. A. (1998). The endogeneity of the optimum currency area criteria. Economic Journal, (108), 1009-1025.

Furceri, D., and Karras, G. (2008). Business-cycle synchronization in the EMU. Applied Economics, (40), 1491-1501.

Gogas, P. (2013). Business cycle synchronisation in the European Union. The effect of the common currency. Journal of Business Cycle Measurement and Analysis, (1).

Gomez, D. M., Ferrari H. J., Torgler, B., and Ortega, G. J. (2017). Synchronization and diversity in business cycles: a network analysis of the European Union. Applied Economics, (49), 972-986.

Gomez, D. M., Ortega, G. I., and Torgler, B. (2012). Synchronization and diversity in business cycles: a network approach applied to the European Union Eastern Europe. (CREMA Working Paper, No. 1).

Harding, D., and Pagan, A. R. (2002). Dissecting the cycle: a methodological investigation. Journal of Monetary Economics,(49), 365-381.

Hodrick, R., and Prescott, E. (1997). Postwar U.S. business cycles: an empirical investigation. Journal of Money, Credit and Banking, (29), 1-16.

Kenen, P. (1969). The theory of optimum currency areas: an eclectic view, In R. Mundell, A. Swoboda (Eds.), Monetary problems of international economy. Chicago: University of Chicago Press. 
Konstantakopoulou, I., and Tsionas, E. (2011). The business cycle in Eurozone economies (1960-2009). Applied Financial Economics, (21), 1495-1513.

Lehwald, S. (2013). Has the Euro changed business cycle synchronization? Evidence from the core and the periphery. Empirica, (40), 655-684.

McKinnon, R. (1963). Optimum currency areas. American Economic Review, (53), 717-725.

Mundell, R. (1961). A theory of optimum currency areas. American Economic Review, (51), 657-665.

Papadimitriou, T., Gogas, P., and Sarantiti, G. A. (2016). Convergence of European Business Cycles: A Complex Networks Approach. Comput Econ, (47), 97-117.

Santos, S., and Rodrigues, M. (2016). Core-periphery business cycle synchronization in Europe and the great recession. Eastern European Economics, (54), 521-546. 